\title{
Auditor independence and professional scepticism in South Africa: Is regulatory reform needed?
}

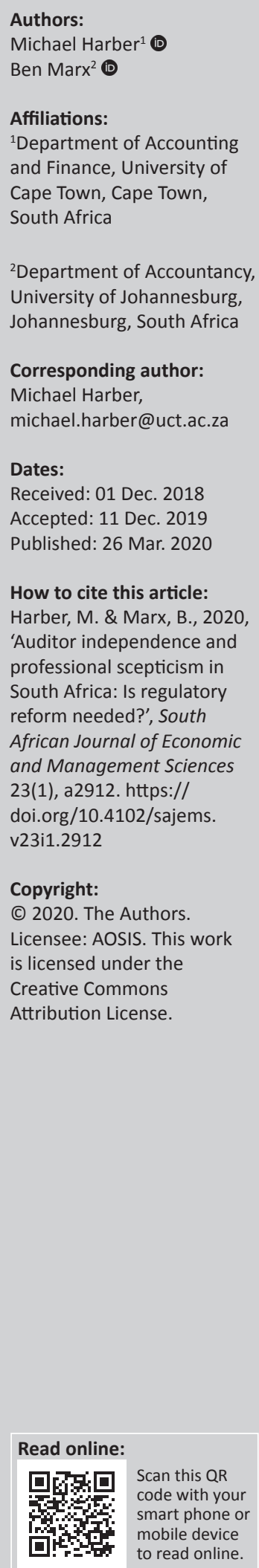

Background: Quality financial reporting, which requires high quality auditing outcomes, aids the smooth functioning of capital markets.

Setting: The South African audit regulator argues that the key auditor attributes of independence and scepticism are dangerously compromised in South Africa, resulting in impaired audit quality. The regulator responded in June 2017 with the issuance of mandatory audit firm rotation (MAFR) regulations, effective April 2023. This ruling has caused considerable debate and opposing views in the audit industry.

Aim: This study explores the state of auditor independence and the degree to which professional scepticism is being exercised by South African auditors of exchange-listed companies through an analysis of the perceptions of experienced key stakeholders. The findings contribute to the rationale behind the regulator's argument for the necessity and efficacy of MAFR.

Method: The study uses a survey methodology across four key stakeholder groups experienced in matters concerning the audit process, auditor appointment and reliance on the audit outcome on the Johannesburg Stock Exchange.

Results: Respondents do not believe that auditor independence and professional scepticism are impaired, nor that existing regulations and codes of practice need amendment. In addition, audit failures and corporate financial scandals are not believed to be a result of compromised auditor independence and professional scepticism, nor do longer audit firm tenures impair independence and professional scepticism.

Conclusion: These perceptions provide evidence against the rationale for MAFR adoption and indicate that it may not be necessary or effective. The study contributes to the South African audit profession in its objective to maintain audit quality. As such, it is relevant to regulators, standard-setters and stakeholders in South African capital markets.

Keywords: Auditing; Corporate governance; Audit quality; Auditor independence; Professional scepticism; Auditor rotation.

\section{Introduction}

Due in part to the continued occurrence of corporate financial scandals and fraudulent financial reporting, auditor independence and professional scepticism have received a great deal of attention from regulators globally (Glover \& Prawitt 2014; Knechel 2016; The Economist 2018a, 2018b). Financial scandals have produced a growing unease among investors and regulators about the adequacy of auditor independence, especially in regard to threats perceived to be presented from long auditor tenures and the impact of non-assurance services (Casterella \& Johnston 2013). Auditors have been accused of lacking the requisite degree of independence and professional scepticism to prevent, detect or 'blow the whistle' on corrupt or negligent behaviour in companies (Independent Regulatory Board for Auditors [IRBA] 2016; Maroun \& Solomon 2014). This criticism of auditors and the consequent loss of confidence in their work may be the result of auditors falling short of societal expectations - a phenomenon referred to as the 'audit expectation-performance gap' (Porter, HÓgartaigh \& Baskerville 2012; The Economist 2018b). This gap, considered an international phenomenon, refers to the performance-expectation difference between auditors and the users of the financial statements (Hay 2015; Porter et al. 2012).

As a result of these concerns, audit regulators have looked to apply stricter auditor rotation regulations to safeguard auditor independence, most notably mandatory audit firm rotation (MAFR). By forcing periodic firm rotation, over and above the more traditional partner rotation, 
the length of audit firm tenures can be reduced. The aim is to preserve independence by limiting the opportunity for auditors to develop relationships with clients, which in turn mitigates the threat to audit quality from compromised independence and professional scepticism (Casterella \& Johnston 2013; Jackson, Moldrich \& Roebuck 2008).

Illustrating the international divide around auditor rotation regulations, the European Union decided to implement MAFR in 2014 (European Commission 2014; KPMG 2014) while the United States has continuously decided against it, favouring partner rotation. Proponents of MAFR argue that long audit firm tenures lead to audit failures from compromised independence and professional scepticism. Opponents counter that it is longer tenure that improves audit quality because it allows the auditor to develop client-specific and industry-specific knowledge and expertise over time.

In June 2017, the Independent Regulatory Board for Auditors (IRBA), the South African statutory body responsible for regulating the auditing profession, followed the European Union's ruling in favour of MAFR for all 'public-interest entities', effective 2023, on a 10-year rotation basis (IRBA $2017 \mathrm{~b}$ ). This regulation would include all companies listed on the Johannesburg Stock Exchange (JSE). The IRBA is moving, therefore, beyond the current system of mandatory audit partner rotation on a five-year rotation basis to firm rotation. Whereas some countries have adopted MAFR in recent years, most have decided against it (Lennox 2014; Shango 2017), continuing to favour partner rotation, as recommended in the International Federation of Accountants (IFAC) Code of Ethics for Professional Accountants (IESBA 2018).

The primary reason for implementing MAFR in South Africa is the concern by the IRBA that the quality of audits performed by audit firms on exchange-listed companies is deteriorating (Harber \& Marx 2019). According to the IRBA (2016), this lack of independence and professional scepticism is evidenced by recent high-profile financial reporting scandals and the poor results of regulatory inspections of audit work. The IRBA performs annual reviews of select audit work performed by audit firms and audit practitioners. The past few years have produced unsatisfactory findings, some of which the IRBA believes are due to a deterioration in independence and growing professional scepticism (IRBA 2017e, 2018, 2019). These concerns are commonly expressed by regulators and inspectors globally as the root cause of audit deficiencies (Nolder \& Kadous 2018).

The purpose of this study is to better understand the state of auditor independence and professional scepticism in South Africa, as a means of contributing to the ongoing debate concerning the necessity and potential efficacy of MAFR. This study thereby conducts an exploratory analysis of the views of experienced auditors, audit committees (ACs), chief financial officers (CFOs) and institutional investors in this regard. According to Ewelt-Knauer, Gold and Pott (2013), there is a gap in the literature around the views of experienced role players, those parties within the audit process, as well as those responsible for auditor appointment. The study addresses this gap and contributes to the controversial and ongoing debate in South Africa regarding the need to strengthen independence regulations and, by implication, the need for MAFR.

\section{Literature review}

Auditor rotation regulation is designed to improve audit quality by limiting auditor-client tenures (Casterella \& Johnston 2013; Knechel 2016). The concept of audit quality is important to auditing research, especially when assessing the impact of regulation (Hay 2015); however, this notion is problematic to define and measure. This problem arises partly because stakeholders of organisations have differing needs with respect to audited financial information, and partly because audit quality cannot be directly measured. Researchers, therefore, resort to the use of imperfect and highly criticised proxies (Knechel et al. 2013). Similarly, with regard to the concept of professional scepticism, Glover and Prawitt (2014) argue that despite its relative simplicity, there is a lack of common understanding or practical guidance on how to define professional scepticism and how this concept can be demonstrated. Nolder and Kadous (2018:1) state that 'professional skepticism [sic.] is a foundational construct in auditing', a description which is consistent with extensive literature reviews performed by Tepalagul and Lin (2015) and Casterella and Johnston (2013), which confirm the importance of auditor independence and auditor scepticism in preserving the quality of the audit outcomes.

\section{Audit quality}

Knechel et al. (2013) explain that:

... the problem of audit quality being in the 'eye of the beholder' is reflected in the broad range of diverse, and sometimes divergent, definitions that have been offered by numerous authorities and individuals over the past 20 years. (p. 387)

DeAngelo (1981:186) provides a helpful definition which, although not all-encompassing, is used in many studies ${ }^{1}$ on audit quality: 'Audit quality is the probability that the auditor will uncover a breach of statutory or regulatory requirements (particularly financial in nature); and report the breach to the appropriate parties.' An alternative definition is proposed by the international auditing standards, which defines a quality audit as one which is performed in accordance with the standards (International Standard on Auditing) 'to obtain reasonable assurance' about whether the financial statements reported by the company to stakeholders are 'free from material misstatement, whether due to fraud or error' and to communicate such findings and opinions to the users of the financial statements and relevant regulatory bodies (IFAC ISA 200, 2009:para.11). It can be clearly seen that the definition provided by DeAngelo (1981) and that of the International Standard on Auditing are consistent.

1This is a usefuld finition that has been adopted in numerous recent studies such as those of Ball, Tyler and Wells (2015), Fontaine et al (2016), Hakwoon, Hyok and those of Ball, Tyler ar Jong Eun (2015), Jackson et al. (2008), Kwon, Lim and Simnett (2014), Lennox, Wu and Zhang (2014), Lu and Sivaramakrishnan (2009) and Tepalagul and Lin (2015). The definition is important because it identifies the purpose of auditing. 


\section{Linking audit quality to mandatory audit firm rotation}

The literature establishes that both high audit quality and an acceptable audit outcome require two auditor attributes. The auditor needs to be both independent of the client and competent and capable (Knechel 2016; Tepalagul \& Lin 2015). A compromise in either attribute will necessarily compromise the quality of the audit. As long audit-client relationships are considered threats to independence in theory (IESBA 2018) and by regulators (IRBA 2016; Roush et al. 2011), auditor rotation requirements (whether partner or firm rotation) are designed to preserve audit quality. Therefore, it stands to reason that if independence is not compromised in South Africa, and if audit failures are a result of a lack of competence, then MAFR may not be necessary or effective. Many of the audit firms have used this argument against the IRBA position (Harber \& West 2017) and as such, this reasoning underlies RQ1 and RQ2 (refer below).

\section{Auditor independence and professional scepticism}

Similarly, professional scepticism is also difficult to define and measure (Hurtt et al. 2013). According to Nolder and Kadous (2018:1), 'the professional skepticism [sic.] construct remains ill-defined and measurements used in research do not map well into practice' and a more definitive conceptualisation of professional scepticism is needed to aid researchers. In terms of professional standards, auditor scepticism is necessary throughout the audit engagement to produce appropriately high-quality audits (IAASB 2018; IESBA 2018; IFAC 2017) and, as such, enhance the degree of user confidence in audited financial statements. This confidence, in turn, aids the proper functioning of capital markets by lowering the risks inherent in financial decisionmaking (Firth, Rui \& Wu 2012).

Scepticism comes from the Greek word 'skeptikos' which means 'inquiring or reflective'. Being a sceptic is often associated with questioning, careful observation, probing reflection, and suspension of belief. 'Professional' scepticism incorporates these attributes within a professional setting, requiring due diligence and a standard of care (Glover \& Prawitt 2014). The international auditing standards define professional scepticism as 'an attitude that includes a questioning mind, being alert to conditions which may indicate possible misstatement due to error or fraud, and a critical assessment of audit evidence' (IFAC ISA 200, 2009:77). These standards go further and assert that scepticism reduces:

\footnotetext{
... the risks of overlooking unusual circumstances, overgeneralizing when drawing conclusions from audit observations, and using inappropriate assumptions in determining the nature, timing, and extent of the audit procedures and evaluating the results thereof. (IFAC ISA 200, 2009:A19)
}

Thus, professional scepticism can be viewed as the force that drives auditors to recognise potential errors and irregularities and to investigate misstatements, should they exist, hence the link between scepticism and audit quality.
Aschauer et al. (2017) explain that auditors are obliged to maintain their professional scepticism, which they explain as being the propensity of an auditor to defer drawing conclusions until the evidence provides sufficient support for one alternative or explanation over another. If the auditor does not maintain professional scepticism or is not independent of the client, due to bias in the client's favour, there is a risk of not seeking sufficient (quantity) or appropriate (quality) auditory evidence upon which to form an opinion. This limitation may result in unreasonable conclusions being drawn regarding accounting, fraud or financial reporting matters. Therefore, the proper application of professional scepticism requires that auditors question the reliability of evidence, remain alert to indicators of fraud and management bias and critically assess the evidence (IESBA 2018; Nolder \& Kadous 2018). Hurtt et al. (2013) extend the framework adopted by Nelson (2009), proposing that a lack of scepticism can either be the result of: (1) a failure in problem recognition, including a lack of sceptical judgement, or (2) a failure to act on a problem recognised, meaning a lack of sceptical action.

The literature and the professional standards show that auditor scepticism and auditor independence from the client are related yet different attributes, both necessary for the production of a high-quality audit outcome. Furthermore, a distinction is made between what the professional standards refer to as 'independence in mind' and 'independence in appearance'. The IFAC Code of Ethics for Professional Accountants explains that independence in the context of the audit comprises both the:

... [S] tate of mind that permits the expression of a conclusion without being affected by influences that compromise professional judgment, thereby allowing an individual to act with integrity and exercise objectivity and professional skepticism [sic.] [independence in mind] ... [as well as] the avoidance of facts and circumstances that are so significant that a reasonable and informed third-party would be likely to conclude, weighing all the specific facts and circumstances, that a firm's or audit team member's integrity, objectivity or professional scepticism have been compromised [independence in appearance]. (IESBA 2018:118-119)

These explanations confirm that the reality of being independent and sceptical, as well as appearing as such to outside parties, is important both to safeguard audit quality and to provide the necessary degree of comfort to users of audited financial information.

These two concepts of auditor 'independence' are always presented together in the IFAC Code of Ethics for Professional Accountants and the IFAC auditing standards (IESBA 2018; IFAC ISA 200, 2009). Despite having different meanings, the two concepts are closely related and used together in the MAFR professional debate and in practice (Harber \& West 2017; IRBA 2016). An auditor who lacks independence will likely lack professional scepticism. As such, the research objectives (refer below) do not deal with each concept separately. 


\section{Long audit firm tenures}

Consistent with the professional IFAC Code of Ethics for Professional Accountants (IESBA 2018), the literature review study of Tepalagul and Lin (2015) illustrates that, in principle, longer auditor tenures (partner or firm tenures) may increase the risk of impaired independence and professional scepticism. Proponents of MAFR are concerned with 'client affiliation' and especially the 'auditor tenure' risks that may occur over long periods during which the auditor-client relationship develops. This close connection is considered to be an incentive for the auditor to acquiesce to client preferences in financial reporting, which are sometimes fraudulent or unreasonable (Bamber \& Iyer 2007). This compliance has also been attributed to the fact that in South Africa, like in most jurisdictions, the audit profession is a for-profit and competitive enterprise as well as a service of public and investor protection (Bergner 2011; Harber 2016). Profit motives may 'incentivise' auditors to succumb to client pressures, compromise their integrity and allow management misconduct and improper financial reporting to go unchallenged.

In an extensive review of the research examining the causes and consequences of auditor switching, Stefaniak, Robertson and Houston (2009) note that most studies look at the association of auditor tenure and various measures of audit quality. In general, they find that audit quality is higher when there is a longer auditor-client relationship, a finding that would seem to mitigate against a policy of MAFR (DeFond \& Francis 2005; Stefaniak et al. 2009). Consistent with the findings of Stefaniak et al. (2009), using archival data, Geiger and Raghunandan (2002) find longer auditor tenure is associated with less audit failure, again providing evidence against MAFR. Ghosh and Moon (2005), Johnson, Khurana and Kenneth Reynolds (2002) and Myers and Oetzel (2003) also find that longer auditor tenure does not reduce financial reporting quality, indicating that MAFR would not lead to improved reporting quality. Consistent with these findings, an extensive review of literature performed by Tepalagul and Lin (2015), reviewing 'published articles during the period 1976-2013 in nine leading journals related to auditing' found that 'most studies concluded that long auditor tenure does not impair independence' (Tepalagul \& Lin 2015:101). Studies investigating audit firm rotation specifically provide more mixed results but again favour the conclusion that audit firm rotation does not improve auditor independence and professional scepticism. Therefore, it appears that the literature does not provide evidence supporting MAFR, considering that MAFR is a regulatory tool designed to limit audit firm tenure.

\section{Study purpose and research questions}

The purpose of this study is to explore whether auditor independence and professional scepticism are indeed considered to be compromised in South Africa, as claimed by the IRBA (IRBA 2016, 2017c). Thereby this study contributes to the debate concerning the necessity for, and efficacy of, MAFR regulation.
The research questions addressed in this study are as follows:

RQ1: Do South African auditors of exchange-listed companies lack the required degree of independence and professional scepticism?

RQ2: Are audit failures in South Africa a result of compromised auditor independence and professional scepticism?

RQ3: In addition to existing measures, will MAFR regulations further increase auditor independence and professional scepticism?

RQ4: Does the investing public believe that auditor independence and professional scepticism are compromised concerning the audits of exchange-listed companies?

Interviews with 14 experienced auditors in South Africa by Harber (2016), conducted with managing directors and senior leadership within their respective firms, reveal strong sentiments by auditors that their independence and professional scepticism are not compromised, and that long audit firm tenures do not reduce independence. Official letters from audit firms to the IRBA on the MAFR debate again demonstrate strong 'push-back' against MAFR, primarily because they do not believe auditors lack independence or professional scepticism. ${ }^{2}$ The CFO Forum, a discussion group for JSE exchange-listed company CFOs, submitted a letter to the IRBA suggesting that CFOs are unconvinced that auditor independence and professional scepticism are compromised (Ramon 2016). This study seeks to extend the research of Harber (2016) to more stakeholder groups, on a larger and more representative sample.

The stakeholder groups deemed best suited to provide an informed perspective on auditor independence and scepticism concerns in the South African context are audit partners (audit practitioners), CFOs, AC chairs and institutional investors. It is submitted that these stakeholder groups represent experienced role players and participants in the audit function in South African capital markets. The AC chair and the auditor represent the two engaging parties in the audit, both with statutory responsibilities to assess and maintain audit quality and independence. The AC conducts a due diligence of the appropriateness of the auditors and annually recommends them to shareholders for appointment at shareholder meetings. The AC also assesses the outcome of the audit, including issues uncovered during the audit and the auditor's recommendations to management. The CFO is the most senior member of the financial function in a company, ultimately responsible for financial decision-making, and the production of the company's financial statements to be distributed to shareholders and other stakeholders. As such, it is the CFO who is responsible for dealing with the auditors during the audit process and for the payment of the audit fees. The investors are here represented by equity fund managers the senior staff of asset management companies who are responsible for managing large amounts of funds on behalf of clients by investing them in shares (equity) of companies and, thereby, representing a significant degree of shareholding in these companies.

2.Refer to Bam (2017), Bourne (2017), Harber and West (2017), Oddy (2017) and Shango (2017). 
Ewelt-Knauer et al. (2013) conclude that there is a need in the literature to explore the perceptions of shareholders specifically concerning the MAFR debate. A survey performed in 2012 by the Organisation for Economic Co-operation and Development (OECD), across its 35 member states, illustrates the role that large institutional investors can play in providing a source of stable, long-term capital. With the goal of optimising returns for targeted levels of risk, as well as for prudential regulation, institutional investors diversify investments into large portfolios, many of them having investments in thousands of companies (OECD 2011). Institutional investors are significant long-term shareholders of companies and represent a major force in many capital markets, with a large degree of influence in corporate governance (Callen \& Fang 2013; Mccahery, Sautner \& Starks 2016; Pozen 2015). The largest portion of shareholding in South African companies is managed by institutional equity fund managers (Harber 2017).

\section{Methods}

This empirical study employs a questionnaire (survey) methodology, with electronic questionnaires distributed by email to participants within the four targeted stakeholder groups, namely audit partners (registered audit practitioners), CFOs, AC chairs and equity fund managers. The same questionnaire with respect to independence and scepticism was distributed to each group.

The questionnaire was sent to audit partners accredited to audit JSE-listed companies as per the latest JSE Listing Requirements (IRBA 2017d; JSE 2017). This list was obtained directly from the JSE and contained 305 registered auditors, after excluding the auditors who had retired since the compilation of the list. The 305 audit partners represented 20 accredited audit firms, with 192 auditors from the Big Four ${ }^{3}$ firms $(63 \%)$.

The questionnaire was distributed to the group-level CFOs of the Top 100 companies listed on the JSE according to market capitalisation, excluding companies with a secondary listing on the JSE exchange (i.e. companies that have a primary listing on a foreign exchange, usually the London Stock Exchange). Each $\mathrm{CFO}$ was requested to send the questionnaire to their group-level AC chair. This list of companies and CFO contacts was obtained directly from the JSE and, according to JSE market statistics as at February 2018, the JSE has a total equity market capitalisation of R14.8 trillion (Main Board and Alt X). Excluding secondary listings, the total market capitalisation of the remaining Top 100 companies is approximately R8 trillion (JSE 2018; Sharenet 2018), representing approximately $92 \%$ of total market capitalisation. As such, this proportion of companies represents a wide spectrum of stakeholders' interests in South African capital markets. According to a review of the latest company records and annual reports for each of the 100 companies, it was determined that 7 individuals act as AC chair on more than one company in the target group 3.The 'Big Four' refers to Deloitte, EY, KPMG and PwC, the four largest international audit firm networks. of 100. Considering that these individuals would only complete the questionnaire once (as the tool is not companyspecific), the total population is 93 .

The questionnaire was distributed to equity fund managers from the 10 largest equity asset and investment management companies in South Africa, responsible for investing thirdparty monies in equity investments. These companies represent the 10 largest equity asset managers in South Africa by way of funds under management, as determined by the records of the Association for Savings and Investment South Africa (ASISA). All the companies are members of, and actively involved with, the ASISA. Based on a consultation with the CEO of ASISA and the records of funds under management as at 30 June 2017, the top 10 companies account for over $85 \%$ of the total equity third-party funds under management by South African asset managers.

The questionnaires were constructed based on existing academic literature and the professional South African debate, as presented in the literature review outlined in this study. A five-point Likert scale design using t-tests, which is commonly employed in survey research (Brunzell, Liljeblom \& Vaihekoski 2015; Daugherty et al. 2012; De Winter \& Dodou 2010), captured respondents' attitudes and opinions, together with opportunities for typed (open-ended) comments. Validity and reliability tests were performed in pilot testing of the surveys with experienced representatives from each participant group. The tables in the analysis of findings below present each separate question or statement in the questionnaire, numbered 1-13.

\section{Response rates achieved}

From the 305 audit partners, 112 complete and usable responses were received, resulting in a $36.7 \%$ response rate. Of the 112 questionnaires received, 66 were from Big Four firm partners (59\%) and 46 (41\%) from non-Big Four partners. From the CFOs and AC chairs, 53 and 41 complete and usable questionnaires were received, resulting in response rates of $53.0 \%$ and $44.1 \%$. With regard to the equity fund managers, at least one response was received from each of the 10 companies. Twenty-one complete and usable responses were received in total, resulting in an average of 2.1 responses per company. The questionnaire was only sent to one senior executive at each company, this being the company's chief investment officer $(\mathrm{CIO})$ and representative on the ASISA investment committee. A request was made by the researchers and the CEO of the ASISA to forward the questionnaire to the 'senior equity fund managers' at the company. Since there is no official definition of an 'equity fund manager', the distribution of the questionnaire was left to their discretion.

Baruch and Holtom (2008), in an examination of organisational survey research response rates, found that the average response rate for studies using data collected from individuals was $52.7 \%$, with a standard deviation of 20.4 . The average response rate for studies that used data collected from organisations was $35.7 \%$, with a standard deviation of 18.8 . 
Reviewing similar auditing and accounting research, Daugherty et al. (2012) achieved a 46\% response, Bamber and Iyer (2007) 23\% and Brazel, Carpenter and Jenkins (2010) $48.8 \%$. Hatfield, Jackson and Vandervelde (2011) justify even a $12.4 \%$ response rate for mailed surveys. Based upon these figures, the response rates achieved in this study across all four participant groups were deemed comparable and acceptable.

\section{Ethical consideration}

The University of Johannesburg FEFS Research Ethics Committee approved the study's ethical clearance with number FEFSREC2017081401.

\section{Results}

Table 1 presents the findings on perceptions of the current status of South African auditors' independence and professional scepticism, as related to JSE-listed company audits (addressing RQ1). The table also presents opinions on the adequacy of existing safeguard measures. It is clear from the findings that responding auditors, AC chairs and CFOs strongly believe (Statement 1 ; all means $>4 ; p<0.001$ ) that auditors possess the required high degree of independence and professional scepticism. Similarly, these three responding groups express strong agreement that current regulations and professional standards in South Africa are sufficient to regulate auditor independence and professional scepticism (Statement 1; all means $<2 ; p<0.001)$. These findings are statistically different from the neutral value of 3 at a $99.9 \%$ confidence level.

With regard to Statement 1 and Statement 2, equity fund managers expressed mixed feelings, with findings that do not differ significantly from neutral. However, the means (3.30 and 2.70) show a slight favour in agreement with the other participant groups. It could be concluded that equity fund managers are furthest removed from the audit appointment, engagement negotiation, audit process and independence assessment relative to the other three participant groups. As such, equity fund managers may be less biased in favour of protecting the status quo as they do not stand to gain or lose directly from any change of regulation and do not themselves directly assess the auditor or their work, as do the auditors and audit committees.

TABLE 1: Perceptions concerning the current status of independence and scepticism.

Statement Mean Standard deviation Difference from neutral

1. South African auditors of listed companies lack the required degree of independence and professional scepticism

$\begin{array}{llll}\text { Audit partners } & 4.23 & 0.95 & 1.23^{* * *} \\ \text { Audit committee chairs } & 4.35 & 0.83 & 1.35^{* * *} \\ \text { Chief financial officers } & 4.21 & 1.04 & 1.21^{* * *} \\ \text { Equity fund managers } & 3.30 & 1.00 & 0.30\end{array}$

2. Current regulators and professional standards in South Africa are sufficient or regulate auditor independence and professional scesspticism

$\begin{array}{llll}\text { Audit partners } & 1.62 & 0.82 & {[1.38]^{* * *}}\end{array}$

Audit committee chairs $1.84 \quad 0.86 \quad[1.16]^{* * *}$

$\begin{array}{llll}\text { Chief financial officers } & 1.61 & 0.75 & {[1.39]^{* * *}}\end{array}$

$\begin{array}{llll}\text { Equity fund managers } & 2.70 & 0.91 & {[0.30]}\end{array}$

Note: Mean endpoints, midpoints: 1 = strongly agree; 3 = neutral; 5 strongly disagree. Values in square brackets indicate a negative number.

$*, * *, * * *$, Denote significance at $\leq 0.05,0.01$ and 0.001 levels (two-tailed).
In addition, it could also be argued that equity fund managers, since they are not directly involved, are the less informed participants in this study.

\section{Separating Big Four from non-Big Four firms}

Regarding the auditors, it is important to separate the views of the Big Four firm respondents from the non-Big Four firm respondents (addressing RQ1). Doing so reveals that both groups are in agreement concerning independence, professional scepticism and the adequacy of regulations. However, the Big Four firm partners expressed more conviction with respect to the standard of auditor independence (Statement 1; mean $=4.52$ ) as opposed to non-Big Four partners $($ mean $=3.83)$. This was again the case with respect to the regulatory and professional framework governing independence (Statement 2; means $=1.42$ and 1.89).

The agreement between Big Four and non-Big Four firm partners is perhaps surprising considering that Big Four firms have been accused of bias against MAFR on the grounds that they stand to lose clients to non-Big Four firms from the increased competition and tendering that will result to secure appointments. It appears that neither group believes auditor independence, nor the current regulatory framework safeguarding independence, is a concern.

Considering that MAFR is primarily designed to improve audit quality by limiting audit firm tenure and, thereby, reducing the alleged familiarity and bias of the auditor towards company management (IRBA 2016, 2017a), the findings in Table 1 provide evidence against its necessity.

Table 2 explores respondents' sentiments concerning independence and scepticism 'in mind', as opposed to 'in appearance', as well as the MAFR debate on the impact of audit firm tenure (addressing RQ1 and RQ3).

Statement 3 shows that all responding groups attribute audit failures to reasons other than a lack of auditor independence and professional scepticism. The comments make it clear that respondents believe audit failures are due to 'negligence' and 'shoddy work' rather than compromised independence. As one respondent articulated, a:

'... lack of knowledge/skills and experience is a bigger risk for failure to detect misstatements because of fraud and error.' (RA38, Audit partner).

According to the literature, audit quality can deteriorate due to either a lack of independence or a lack of capability or competence (Tepalagul \& Lin 2015). If auditor failure is a result of poor quality audit work caused by deficient skills and capability or negligent behaviour, this is not likely to be rectified by audit firm rotation.

Statements 4-6 provide results that do not favour adoption of MAFR. Responding auditors, AC chairs and CFOs reject the premise that longer audit firm tenures result in less independence and professional scepticism $(p<0.001)$. MAFR 
TABLE 2: Perceptions concerning audit failure and audit firm tenure.

\begin{tabular}{lccc}
\hline Statement & Mean & $\begin{array}{c}\text { Standard } \\
\text { deviation }\end{array}$ & $\begin{array}{c}\text { Difference } \\
\text { from neutral }\end{array}$ \\
\hline 3. In your experience, failure by auditors to detect material financial reporting \\
misstatements (due to fraud or error) is due to a lack of auditor independence. \\
Audit partners & 4.15 & 0.77 & $1.15^{* * *}$ \\
Audit committee chairs & 4.02 & 0.83 & $1.02^{* * *}$ \\
Chief financial officers & 4.00 & 0.88 & $1.00^{* * *}$ \\
Equity fund managers & 3.52 & 0.83 & $0.52^{* *}$ \\
4. Longer audit firm tenures result in less auditor independence. & \\
Audit partners & 3.82 & 1.00 & $0.82^{* * *}$ \\
Audit committee chairs & 3.69 & 1.06 & $0.69 * * *$ \\
Chief financial officers & 3.77 & 1.01 & $0.77^{* * *}$ \\
Equity fund managers & 2.70 & 0.95 & {$[0.30]$} \\
5. MAFR provides auditors with the incentive to be more alert and pay closer \\
attention to detail, since they know that their work will be reviewed by another \\
firm after rotation occurs. \\
Audit partners & 3.70 & 1.07 & $0.70^{* * *}$ \\
Audit committee chairs & 3.45 & 1.07 & $0.45^{* *}$ \\
Chief financial officers & 3.32 & 1.18 & $0.32^{*}$ \\
Equity fund managers & 2.83 & 0.96 & {$[0.17]$} \\
6. MAFR will increase the independence of audit firms (and audit partners). \\
Audit partners & 3.84 & 1.03 & $0.84^{* * *}$ \\
Audit committee chairs & 3.69 & 1.03 & $0.69 * * *$ \\
Chief financial officers & 3.67 & 1.01 & $0.67 * * *$ \\
Equity fund managers & 2.83 & 0.87 & {$[0.17]$} \\
\hline
\end{tabular}

Note: Mean endpoints, midpoints: 1 = strongly agree; 3 = neutral; 5 strongly disagree. Values in square brackets indicate a negative number.

$*, * *, * * *$, Denote significance at $\leq 0.05,0.01$ and 0.001 levels (two-tailed).

MAFR, mandatory audit firm rotation.

is not believed to produce more diligent and attentive auditors (Statement 5) nor will it increase the independence of auditors (Statement 6). However, the fund managers again expressed mixed findings, with means close to neutral. Interestingly, each mean result shows a tendency to the opposite opinion of the other three groups, even though not statistically different from neutral.

In the comments, one CFO explained that audit work and financial statements were reviewed:

'... by IRBA, [the audit firm's] own rigorous internal review procedures and the JSE.' (RA5, Audit partner)

Thereby ensuring a high degree of quality. In the words of another CFO:

'... audit working papers are already subject to IRBA, JSE and internal firm reviews - surely that's adequate?' (CFO27, Chief financial officer).

\section{A different CFO stated that:}

'... auditors do not need MAFR to worry about the quality of their work. The JSE, IRBA, other regulators and public are enough pressure.' (CFO44, Chief financial officer).

In addition, a common theme that emerged was the feeling that:

'... auditors will not have their independence impaired for a client as they risk their livelihoods.' (RA7, Audit partner).

The risk of lost reputation and litigation against the auditor was a deterrent to compromising audit quality. Further comments from the CFOs include:
'In the two decades I have been dealing with our current firm I have never had the impression that they ever lacked independence. It depends on individual people and some will always remain independent while others may lose their independence on day 1. I have developed very strong professional relationships with our auditors, but they will always remain independent.' (CFO10, Chief financial officer)

'In my 23 years of experience in financial reporting, I have never had any reason to even come close to questioning the independence of any of the audit firms that I have dealt with.' (CFO6, Chief financial officer)

Furthermore, contrary to the IRBA reasoning that longer tenure impairs independence, respondents argued that independence may actually be a concern early in the tenure, not after years of appointment, because:

'The new auditors will try hard to build and establish good relationships at the new audit client which will also have an unintended consequence of staying clear of certain contentious accounting, auditing, taxation, etc. points.' (RA91, Audit partner)

This view is the result of opposite reasoning to that of the IRBA's which is in favour of MAFR. As expressed by one auditor, the:

'... [newly appointed] auditors will be on the back foot and will have to concede on a lot of important judgemental points because challenging well-established professional management of these complex clients will make them look less astute that the previous auditor.' (RA56, Audit partner)

This lack of experience in comparison to the outgoing audit firm may impair the independence of the auditor, resulting in acquiescence to the judgement of management with respect to complex company-specific or industry-specific accounting matters. Given the size and complexity of large, exchangelisted multinational companies, MAFR may have the unintended consequence of incentivising new auditors to:

'... stay clear of certain contentious accounting, auditing, taxation, etc. points.' (RA91, Audit partner).

This reasoning by some respondents is contrary to the proMAFR position and is consistent with the opinions expressed by senior managing partners in the interview-based study conducted by Harber (2016).

\section{The argument of Independent Regulatory Board for Auditors inspection findings and corporate failures}

The IRBA argues that inspections of auditors and audit work reveal increasing instances of non-compliance with ethical and independence regulations which provides evidence that independence is compromised (IRBA 2016). The findings highlight non-compliance with ethical and independence requirements, the root cause of which is described by the IRBA as the:

'... failure to fortify the importance of professional scepticism and the independence of the engagement team so as to overcome the threats that could develop as a result of their relationship with clients.' (IRBA 2015:13) 
TABLE 3: Perceptions concerning the Independent Regulatory Board for Auditors' inspection findings and corporate failures.

\begin{tabular}{|c|c|c|}
\hline Statement & Yes (\%) & No (\%) \\
\hline \multicolumn{3}{|c|}{$\begin{array}{l}\text { 7. Regarding the unsatisfactory findings based on the IRBA inspections of auditors, } \\
\text { are you of the opinion that these findings strengthen the argument of the IRBA in } \\
\text { favour of MAFR? } \dagger\end{array}$} \\
\hline Audit partners & 9.5 & 90.5 \\
\hline Audit committee chairs & 27.9 & 72.1 \\
\hline Chief financial officers & 21.3 & 78.7 \\
\hline Equity fund managers & 69.6 & 30.4 \\
\hline \multicolumn{3}{|c|}{$\begin{array}{l}\text { 8. Regarding the IRBA argument for MAFR based on the occurrence of high-profile } \\
\text { corporate failures, are you of the opinion that this IRBA reasoning strengthens } \\
\text { their case in favour of MAFR? } \dagger\end{array}$} \\
\hline Audit partners & 20.6 & 79.4 \\
\hline Audit committee chairs & 25.6 & 74.4 \\
\hline Chief financial officers & 18.0 & 82.0 \\
\hline Equity fund managers & 47.8 & 52.2 \\
\hline
\end{tabular}

Note: Mean endpoints, midpoints: 1 = strongly agree; 3 = neutral; 5 strongly disagree.

$\dagger$, Respondents were provided a short explanation of the IRBA arguments from the inspection findings and the corporate failures.

IRBA, Independent Regulatory Board for Auditors; MAFR, mandatory audit firm rotation.

As another key argument for the necessity of MAFR, the IRBA highlights the continuing occurrence of corporate failures that result from management fraud and misconduct, claiming that these incidents provide further evidence of impaired auditor independence. Respondents' views regarding these two arguments were collected in Statement 7 and Statement 8, as shown in Table 3 (addressing RQ1 and RQ2).

It appears that while responding fund managers believe that these IRBA inspection findings add credibility to the IRBA reasoning, the other three participants do not. It is submitted that the auditors are most affected by, as well as most informed regarding, the public inspections process as it is their engagement audit files and their firms' policies and procedures that the IRBA is 'auditing'. The responding partners would have all had experience of the inspectorate's reviews of their audit firms, as well as individual audit engagements in which they acted as the engagement partner. From a review of responding auditor comments regarding these inspection findings, partners expressed that these findings most likely reflect instances of poor documentation of ethical consideration and should not be confused with actual compromised independence. The auditors explained that 'signing ethics confirmations are considered to be independence findings' for the IRBA and this view is unreasonable because independence is a state of mind and action. As such the IRBA conclusion that ethics are compromised 'is misleading'. This interpretation presents an important distinction the auditor respondents make concerning the IRBA findings - it is not a representation of impaired independence:

'We have not seen evidence that the IRBA findings are independence-related.' (RA91, Audit partner)

'The issues raised in the IRBA findings relate more to the formal documentation of thought processes applied by the independent auditor than $[t o]$ a state of mind issue regarding the need to remain independent.' (RA90, Audit partner)

Even the CFOs' comments raised these concerns:

'I would question whether the "unsatisfactory inspection results" and auditor independence is fully correlated and potentially question whether there are not several other, less severe reasons behind the perceived deterioration.' (CFO26, Chief financial officer)

'To my knowledge, IRBA has not published any report on audit failures where there was a failure in auditor independence.' (CFO10, Chief financial officer)

Respondents appear to believe that the inspection results show evidence of poor documentation of ethical and independence considerations and procedures; however, this outcome is not indicative of poor independence in 'fact and mind'. Respondents also raised serious concerns regarding the quality and intention of the IRBA practice reviews, indicating that they believed the system and processes of the IRBA regarding these reviews were flawed and needed improvement:

'The regression in inspection results is due to the poor quality of reviews by the regulator and their unpractical approach to reviews.' (RA67, Audit partner)

'Inspectorate currently lacks knowledge, level of inspections are very shallow, with not enough balance being given to risk and judgement. To a large extent this is as a result of the calibre of individuals performing the inspections. Tends to be a tick box exercise.' (RA12, Audit partner)

Although the findings for Statement 8 suggest mixed feelings from responding fund managers, the general consensus among the other participant groups is that the occurrence of high-profile corporate failures and the alleged questioning of auditor independence by investors does not provide evidence in support of the MAFR ruling. As will be discussed below, it does not appear that the respondents believe that the investing public are questioning auditor independence. In addition, the results from Statement 1 and Statement 2 (Table 1) show that the respondents do not themselves believe auditor independence is compromised.

Respondents stated that there were multiple reasons for corporate failures and that most of them related to factors other than audit failures and independence concerns. A common theme in the comments is that they were:

'... not aware of any case where corporate failures have been attributed to lack of auditor independence ...' (RA48, Audit partner)

and:

'... not one corporate failure in South Africa has been linked to independence issues.' (RA12, Audit partner).

'I am not aware of any corporate failures in South Africa which can be directly attributed to the role and independence of auditors. There is a tendency to attack the last man standing when a corporate failure occurs i.e. the auditors. There are many reasons for corporate failures.' (ACC10, Audit committee chair)

Some respondents argued that even the current, highly topical and controversial alleged audit firm failures in South Africa were yet be proven as resulting from a dearth of 
TABLE 4: Perceptions concerning independence and scepticism 'in appearance'. Statement Mean Standard deviation Difference from neutral 9. The investing public tend to believe that there is a significant degree of bias or familiarity between auditor and company, causing them to question the quality of the audit opinion and function of the auditor as a whistle-blower.

$\begin{array}{llll}\text { Audit partners } & 3.30 & 1.03 & 0.30^{* *} \\ \text { Audit committee chairs } & 3.48 & 1.05 & 0.48^{* *} \\ \text { Chief financial officers } & 3.67 & 1.01 & 0.67 * * * \\ \text { Equity fund managers } & 3.05 & 1.02 & 0.05\end{array}$

10. Any perceived problems regarding auditor independence by the investing public primarily result from their knowledge of long audit firm tenures.

Audit partners

$0.98 \quad 0.45 * * *$

1.05

$0.40 *$

Chief financial officers $\quad 3.31$

1.12

$0.31 *$

Equity fund managers

3.14

0.87

0.14

11. It is common during company AGMs for the audit committee to be questioned by shareholders on the perception of the independence of the auditors.

$1.05-0.41 * * *$

Audit committee chairs $\quad 3.88$

Chief financial officers $\quad 3.72$

0.70

1.10

$0.88^{* * *}$

3.72

$0.72 * * *$

12. During company AGMs, it is common for shareholders to vote against the resolution to reappoint auditors, on the grounds of concerns regarding long audit firm tenure.

Audit partners 3.72

Audit committee chairs $\quad 4.00$

$0.93 \quad 0.72 * * *$

0.69

$1.00 * * *$

Chief financial officers $\quad 4.12$

0.79

$1.12 * * *$

Equity fund managers

3.82

0.72

$0.82 * * *$

13. MAFR will be effective in changing any perceptions of a lack of independence in the minds of the investing public.

$\begin{array}{llll}\text { Audit partners } & 3.81 & 0.97 & 0.81^{* * *} \\ \text { Audit committee chairs } & 3.67 & 0.92 & 0.67^{* * *} \\ \text { Chief financial officers } & 3.57 & 0.89 & 0.57^{* * *} \\ \text { Equity fund managers } & 2.91 & 0.79 & {[0.09]}\end{array}$

Note: Mean endpoints, midpoints: 1 = strongly agree; 3 = neutral; 5 strongly disagree. Values in square brackets indicate a negative number.

$*, * *, * * *$, Denote significance at $\leq 0.05,0.01$ and 0.001 levels (two-tailed).

MAFR, mandatory audit firm rotation.

auditory independence as opposed to 'shoddy work' such as a lack of competency, as discussed above:

'There is no direct correlation between corporate failures and the issue of auditor independence. Most corporate failures are as a direct result of lack of honesty and integrity by management. You cannot legislate against dishonesty!' (RA109, Audit partner)

The findings from Statement 7 and Statement 8 again provide evidence against the IRBA position and the MAFR ruling.

\section{Independence in appearance}

Finally, the aspect of 'independence in appearance' is considered (addressing RQ4). Whereas 'independence in mind' impacts audit quality, it is in fact auditor 'independence in appearance' that impacts investor trust in the audit function and, consequently, the integrity of financial reporting. The IRBA believes that the MAFR ruling will result in a muchneeded increase in investor confidence with regard to auditor independence and audit quality (IRBA 2016). However, the findings from Table 4, Statement 9, indicate that responding auditors, AC chairs and CFOs do not believe that the investing public has lost trust in auditors and do not generally call into question the quality of the audit opinion and function of the auditor as a whistle-blower (means $>3 ; p<0.01$ ). The responding fund managers again expressed a neutral view.
The comments provided by respondents suggest that it is not investors who have lost trust in the quality of the audit opinion, but rather sections of the general public. Some respondents' comments stated that the general public sometimes expresses views that auditors lack integrity or independence, but this was not true of the more informed investing public. The general public was believed to have 'a perception driven by financial journalism' which, in the view of some respondents, distorted the real state of affairs in the profession and misinterpreted the role and function of the auditor. This view is consistent with the expectation gap theory (Hay 2015; Monroe \& Woodliff 1994; Porter et al. 2012).

All participant groups have considerable experience in attending company shareholder meetings, especially the annual general meetings (AGMs). Findings from Statement 11 and Statement 12 show that investors are not in the habit of querying the board at AGMs concerning auditor independence nor do they commonly vote against the reappointment of the auditor on grounds of long tenure (all means $>3.60 ; p<0.001$ ). The findings from Statement 10 also suggest that when investors are concerned about compromised independence and professional scepticism, it is not on the grounds of familiarity threats and bias produced by long audit firm tenures. As one auditor explained with regard to investors considering only audit firm tenures:

'In the absence of the full picture, as auditors would explain to the audit committee annually how they manage their independence, to leave it to the public/investment community to decide on independence using one factor is downright silly and misleading.' (RA107, Audit partner)

This comment highlights the argument by opponents of MAFR that audit committees are best informed, skilled and experienced, as those charged with governance, to properly assess - on the shareholders' behalf - the independence of auditors. This claim is perhaps understood by most investors and is a reason why the findings of this survey suggest that investors do not question the audit committee's choice of auditor. After all, it is this audit committee, which comprises only non-executive directors in South Africa (for exchangelisted companies), that the shareholders have appointed. Comments were made by respondents to the effect that the IRBA is confusing the perceptions of informed investors with those of the relatively uninformed general public with respect to auditor independence and long firm tenures, thereby concluding that the public has lost trust in the external audit function.

Lastly, findings from Statement 13 show that responding auditors, AC chairs and CFOs do not agree with the IRBA that MAFR will be effective in changing investor perceptions. The fund managers expressed statistically neutral sentiments, suggesting that, unlike the other stakeholder groups, they are less confident that MAFR will not be effective in this regard. The results for responding fund managers in Statements 9, 10 and 13 , although all statistically neutral, suggest that the fund managers were not as assured as the other responding groups in their disagreement with the IRBA. Overall, 
however, once again these findings do not provide support for the IRBA position on MAFR in South Africa.

\section{Summative results}

The findings shed further light on the perceptions of stakeholders within the South African MAFR debate and the perceived 'crisis in the audit profession' (Hannington 2015; Hay 2015) which some believe is caused by compromised auditor independence. The findings (addressing RQ1, RQ2, RQ3 and RQ4) present considerable evidence against the IRBA position on the state of auditor independence and professional scepticism in South Africa and the necessity for, or potential efficacy of, MAFR regulation. Responding auditors, AC chairs and CFOs have extensive experience with respect to the management, governance (including auditor appointment) and financial reporting of large public-interest companies in South Africa, and it can be concluded that they do not believe that:

- Auditor independence and professional scepticism are impaired (Statement 1).

- Current regulations and standards over auditor independence and professional scepticism need improvement (Statement 2).

- Audit failures are a result of a lack of auditor independence and professional scepticism (Statement 3).

- Longer audit firm tenures impair independence and professional scepticism (Statement 4).

- MAFR will increase the independence of auditors (Statement 6).

- The IRBA inspection results or the occurrence of corporate failures strengthen the IRBA position on MAFR (Statement 7 and Statement 8).

- Investors are concerned or exhibit distrust of the independence of auditors and their ability to apply professional scepticism (Statement 9).

The equity fund managers, however, provide a better representation of investors in South African companies and hence their views are particularly important. The findings have shown mostly neutral views and more research is needed to understand with clarity their position on these matters. The only statistically significant results from responding fund managers were those in response to Statements 3, 11 and 12. These responses provide evidence against the IRBA position, especially the findings from Statement 3 which show that fund managers' experience of audit failures is not considered to be due to compromised auditor independence and professional scepticism. As with other participant groups, audit failures are considered instead to be a result of negligence or a lack of skill and competence on the part of individual auditors. These results provide evidence in support of the findings of Stefaniak et al. (2009) and Tepalagul and Lin (2015), which maintain that auditor tenure does not compromise auditor independence.

Concerning the audit expectation-performance gap, as a result of which auditors often fall short of society's expectations, and are quickly blamed for corporate failures (Porter et al. 2012), as has been the case in recent years in the media (Hill 2018; Peyper 2017; The Economist 2018a, 2018b), the results of this study suggest that investors do not believe auditor independence is to blame.

\section{Conclusion}

The results of this study provide evidence against the benefits of introducing MAFR and reinforce views expressed by auditors (Harber 2016) and other responding parties (Harber \& West 2017) to the IRBA during the consultation process. In addition, this research contributes to the perception-based research on MAFR and the strong 'push-back' from many stakeholders internationally against MAFR (Choudhury 2016; Ewelt-Knauer et al. 2013; Fontaine, Khemakhem \& Herda 2016). Overall, the study's findings indicate that experienced audit industry participants do not believe MAFR is necessary, nor will it be effective, contrary to the view of the IRBA. As such, this study has implications for future research, as well as for regulators, both within and outside of South Africa. The opinions of these experienced key stakeholder groups should be considered by the IRBA as they support the United States' position of rejecting MAFR in favour of audit partner rotation, as is currently the practice in South Africa (until April 2023). The IRBA should seek further evidence and reasoning as to why MAFR is necessary and consider the options of amending or retracting the legislation accordingly. If auditor independence is indeed not impaired, or if limiting audit firm tenures will not improve independence, then it stands to reason that MAFR is not necessary.

This research has certain limitations. Care should be taken when drawing inferences from its results, because this study reports only the perceptions of stakeholders, albeit those experienced with auditor appointment. Further, it is acknowledged that AC chairs, CFOs and especially auditors may have a preconceived dislike for MAFR and, therefore, the data could suffer from demand effects due to bias. In addition, there may be bias from respondents since MAFR becomes only effective in April 2023 and hence the regulations could be influenced, amended or appealed before this date. These facts may incentivise respondents to overstate the costs of MAFR while understating its benefits. The researchers attempted to counter this problem by starting the questionnaire with a clear explanation that the intention of MAFR is to protect audit quality and auditor independence. Finally, considering the professional roles, seniority and experience of the individuals targeted in this study, it is submitted that the risk to the quality of the data from these biases is limited.

\section{Acknowledgements Competing interests}

The authors have declared that no competing interest exists.

\section{Authors' contributions}

Both authors contributed equally to the research, the writing of the article, as well as the review process to finalise the article for submission. 


\section{Funding information}

This research received no specific grant from any funding agency in the public, commercial or not-for-profit sectors.

\section{Data availability statement}

The data generated by this study are available on reasonable request from the corresponding author.

\section{Disclaimer}

The views and opinions expressed in this article are those of the authors and do not necessarily reflect the official policy or position of any affiliated agency of the authors.

\section{References}

Aschauer, E., Fink, M., Moro, A., Van Bakel-Auer, K. \& Warming-Rasmussen, B., 2017, 'Trust and professional skepticism [sic.] in the relationship between auditors and clients: Overcoming the dichotomy myth', Behavioral Research in Accounting 29(1), 19-42. https://doi.org/10.2308/bria-51654

Ball, F., Tyler, J. \& Wells, P., 2015, 'Is audit quality impacted by auditor relationships?', Journal of Contemporary Accounting \& Economics 11(2), 166-181. https://doi. org/10.1016/j.jcae.2015.05.002

Bam, L., 2017, Chief Executive Officer of Deloitte Inc. South Africa-Response to the IRBA Consultation Paper on MAFR, 20 January 2017, Received directly from Deloitte Inc.

Bamber, E.M. \& Iyer, V.M., 2007, 'Auditors' identification with their clients and its effect on auditors' objectivity', Auditing: A Journal of Practice \& Theory 26(2), 1-24. https://doi.org/10.2308/aud.2007.26.2.1

Baruch, Y. \& Holtom, B.C., 2008, 'Survey response rate levels and trends in organizational research', Human Relations 61(8), 1139-1160. https://doi. org $/ 10.1177 / 0018726708094863$

Bergner, J.M., 2011, 'Auditor rotation and auditor independence: An investigation using social identity theory and accountability', thesis, The Graduate School, University of Kentucky.

Bourne, M., 2017, Professional Practice Director of EY Inc. South Africa-Response to the IRBA Consultation Paper on MAFR, 20 January 2017, Received directly from EY Inc.

Brazel, J.F., Carpenter, T.D. \& Jenkins, J.G., 2010, 'Auditors' use of brainstorming in the consideration of fraud: Reports from the field', The Accounting Review 85(4), 1273-1301. https://doi.org/10.2308/accr.2010.85.4.1273

Brunzell, T., Liljeblom, E. \& Vaihekoski, M., 2015, 'Short-term expectations in listed firms: The effects of different owner types', Journal of International Financial Management and Accounting 26(3), 223-256. https://doi.org/10.1111/ jifm.12028

Callen, J. \& Fang, X., 2013, 'Institutional investor stability and crash risk: Monitoring versus short-termism?', Journal of Banking \& Finance Journal 37(8), 3047-3063. https://doi.org/10.1016/j.jbankfin.2013.02.018

Casterella, J.R. \& Johnston, D., 2013, 'Can the academic literature contribute to the debate over mandatory audit firm rotation?', Research in Accounting Regulation 25(1), 108-116. https://doi.org/10.1016/j.racreg.2012.11.004

Choudhury, F., 2016, 'Mandatory audit firm rotation - Are we going "round in circles"?', IFAC online, 18 October, viewed 02 February 2017, from https://www. ifac.org/global-knowledge-gateway/viewpoints/mandatory-audit-firm-rotationare-we-going-round-circles.

Daugherty, B.E., Dickins, D., Hatfield, R.C. \& Higgs, J.L., 2012, 'An examination of partner perceptions of partner rotation: Direct and indirect consequences to audit quality', Auditing: A Journal of Practice \& Theory 31(1), 97-114. https://doi. org/10.2308/ajpt-10193

DeAngelo, L.E., 1981, 'Auditor size and audit quality', Journal of Accounting and Economics 3(3), 183-199. https://doi.org/10.1016/0165-4101(81)90002-1

DeFond, M.L. \& Francis, J.R., 2005, 'Audit research after Sarbanes-Oxley', Auditing 24(Suppl. 1), 5-30. https://doi.org/10.2308/aud.2005.24.s-1.5

De Winter, J.C.F. \& Dodou, D., 2010, 'Five-point Likert items: $t$ test versus MannWhitney-Wilcoxon', Practical Assessment, Research \& Evaluation 15(11), 1-16.

European Commission, 2014, 'Directorate-General for financial stability, EU audit reform', Directive 2014/56/EU and Regulation 537/2014, viewed 02 May 2016 from https://ec.europa.eu/info/business-economy-euro/company-reporting-andauditing/auditing-companies-financial-statements_en\#audit-reform-in-the-eu.

Ewelt-Knauer, C., Gold, A. \& Pott, C., 2013, 'Mandatory audit firm rotation: A review of stakeholder perspectives and prior research', Accounting in Europe 10(1), 27-41. https://doi.org/10.1080/17449480.2013.772717

Firth, M., Rui, O.M. \& Wu, X., 2012, 'How do various forms of auditor rotation affect audit quality? Evidence from China', The International Journal of Accounting 47(1), 109-138. https://doi.org/10.1016/j.intacc.2011.12.006
Fontaine, R., Khemakhem, H. \& Herda, D.N., 2016, 'Audit committee perspectives on mandatory audit firm rotation: evidence from Canada', Journal of Management and Governance 20(3), 485-502. https://doi.org/10.1007/s10997-015-9308-2

Geiger, M. \& Raghunandan, K., 2002, 'Auditor tenure and audit reporting failures', Auditing: A Journal of Practice \& Theory 21(1), 67-78. https://doi.org/10.2308/ aud.2002.21.1.67

Ghosh, A. \& Moon, D., 2005, 'Auditor tenure and perceptions of audit quality', The Accounting Review 80(2), 585-612. https://doi.org/10.2308/accr.2005.80.2.585

Glover, S.M. \& Prawitt, D.F., 2014, 'Enhancing auditor professional skepticism: The professional skepticism continuum', Current Issues in Auditing 8(2), P1-P10. https://doi.org/10.2308/ciia-50895

Hakwoon, K., Hyoik, L. \& Jong Eun, L., 2015, 'Mandatory audit firm rotation and audit quality', The Journal of Applied Business Research 31(3), 1089-1106. https://doi. org/10.19030/jabr.v31i3.9245

Hannington, A., 2015, 'Who wants to be an auditor?', Financial Mail, August 27September 02, p. 16, viewed from http://www.financialmail.co.za/opinion/ onmymind/2015/08/27/on-my-mind-who-wants-to-be-an-auditor.

Harber, M., 2016, 'An analysis of audit partner perceptions regarding the state of auditor independence in South African audit firms', in Proceedings of the Southern African Accounting Association Conference, pp. 6-24, Cape Town, September.

Harber, M., 2017, 'The role of institutional investors in promoting long-term value creation: A South African perspective', African Review of Economics and Finance 9(1), 272-291.

Harber, M. \& Marx, B., 2019, 'An analysis of the possible impact of mandatory audit firm rotation on the transformation and market concentration of the South African audit industry', Journal of Economic and Financial Sciences 12(1), a227. https://doi.org/10.4102/jef.v12i1.227

Harber, M. \& West, S., 2017, 'An analysis of the IRBA consultation paper on mandatory audit firm rotation together with key organisation responses', in 2017 Southern African Accounting Association: Biennial International Conference Proceedings, pp. 141-170, KZN, Drakensburg.

Hatfield, R.C., Jackson, S.B. \& Vandervelde, S.D., 2011, 'The effects of prior auditor involvement and client pressure on proposed audit adjustments', Behaviora Research in Accounting 23(2), 117-130. https://doi.org/10.2308/bria-10064

Hay, D., 2015, 'The frontiers of auditing research', Meditari Accountancy Research 23(2), 158-174. https://doi.org/10.1108/MEDAR-12-2014-0062

Hill, L., 2018, 'Auditor-General says KPMG, Nkonki had time to explain', Moneyweb, 25 April, viewed 27 April 2018, from https://www.moneyweb.co.za/news/ companies-and-deals/auditor-general-says-kpmg-nkonki-had-time-to-explain/.

Hurtt, R., Brown-Liburd, H., Earley, C. \& Krishnamoorthy, G., 2013, 'Research on Auditor Professional Skepticism: Literature synthesis and opportunities for future research', Auditing: A Journal of Practice \& Theory 32(Supplement 1), 45-97. research', Auditing: A Journal of Pract
https://doi.org/10.2308/ajpt-50361

IAASB, 2018, 'Professional skepticism lies at the heart of a quality audit', The International Auditing and Assurance Standards Board (IAASB) Communique. PS Focus, October, 1-2.

IESBA, 2018, International Ethics Standards Board for Accountants (IESBA) International Code of Ethics for Professional Accountants, 2018 edition, The International Federation of Accountants (IFAC), New York, viewed from https://www.ethicsboard.org/iesba-code.

IFAC, 2017, Toward enhanced professional skepticism report: IAASB-IAESB-IESBA Professional Skepticism Working Group, viewed 15 November 2017 from https:// www.ifac org/publications-resources/toward-enhanced-professional-skepticism.

IFAC International standard on auditing 200 (ISA 200) 2009, Overall objectives of the independent auditor and the conduct of an audit in accordance with internationa standards on auditing. The International Federation of Accountants, viewed 15 January 2016, from https://www.ifac.org/publications-resources/basisconclusions-isa-200-revised-and-redrafted.

IRBA, 2015, IRBA 2014/2015 Public Inspections Report, The Independent Regulatory Board for Auditors, viewed 05 November 2015, from http://www.paab.co.za/ dmdocuments/Public Inspections Report 2015.pdf.

IRBA, 2016, The IRBA Consultation Paper, The Independent Regulatory Board for Auditors, viewed 15 November 2016, from https://www.irba.co.za/newsheadlines/press-releases.

IRBA, 2017a, Frequently asked questions on MAFR, The Independent Regulatory Board for Auditors, viewed 14 October 2017, from https://www.irba.co.za/newsheadlines/press-releases.

IRBA, 2017b, Gazetted rule of Mandatory Audit Firm Rotation - Gazette No. 40888 , The Independent Regulatory Board for Auditors, viewed 09 June 2017, from https://www.irba.co.za/news-headlines/general-news/rule-on-mandatory-audit firm-rotation.

IRBA, 2017c, IRBA Newsletter 37, The Independent Regulatory Board for Auditors, viewed 02 May 2017, from, https://www.irba.co.za/library/irba-news.

IRBA, 2017d, JSE accreditation of auditors - New listings requirements, The Independent Regulatory Board for Auditors Inspections Department, 10 November, viewed 18 March 2018, from https://www.irba.co.za/upload/ report_files/36.-Inspections-for-JSE-Accreditation_Nov-2017.pdf.

IRBA, 2017e, Public Inspections report 2016, The Independent Regulatory Board for Auditors, viewed 15 October 2017, from https://www.irba.co.za/news-headlines/ press-releases.

IRBA, 2018, Public Inspections report 2017, The Independent Regulatory Board for Auditors, viewed 03 May 2018, from https://www.irba.co.za/guidance-to-ras/ inspections/reports. 
IRBA, 2019, Public Inspections report 2018, The Independent Regulatory Board for Auditors, viewed 13 September 2019, from https://www.irba.co.za/guidance-toras/inspections/reports.

Jackson, A.B., Moldrich, M. \& Roebuck, P., 2008, 'Mandatory audit firm rotation and audit quality', Managerial Auditing Journal 23(5), 420-437. https://doi. org/10.1108/02686900810875271

Johnson, V., Khurana, I. \& Kenneth Reynolds, J., 2002, 'Audit-firm tenure and the quality of financial reports', Contemporary Accounting Research 19(4), 637-660. https://doi.org/10.1506/LLTH-JXQV-8CEW-8MXD

JSE, 2017, JSE limited listings requirements, New amendments effective from 19 June 2017, viewed 02 April 2018, from https://www.jse.co.za/content/ JSERulesPoliciesandRegulationltems/JSEListingsRequirements.pdf.

JSE, 2018, JSE weekly statistics, viewed 23 May 2018, from https://www.jse.co.za/ services/market-data/market-statistics.

Knechel, W., Krishnan, G.V., Pevzner, M., Shefchik, L.B. \& Velury, U.K., 2013, 'Audit quality: Insights from the academic literature', Auditing: A Journal of Practice \& Theory 32(1), 385-421. https://doi.org/10.2308/ajpt-50350

Knechel, W.R., 2016, 'Audit quality and regulation', International Journal of Auditing 20(3), 215-223. https://doi.org/10.1111/ijau.12077

KPMG, 2014, EU Audit Reform - What you need to know (Factsheet)', viewed 15 October 2016, from https://www.kpmg.com/BE/en/IssuesAndinsights/ ArticlesPublications/Documents/EU-Audit-Reform-Fact-Sheet-MFR.pdf.

Kwon, S.Y., Lim, Y. \& Simnett, R., 2014, 'The effect of mandatory audit firm rotation on audit quality and audit fees: Empirical evidence from the Korean audit market' Auditing: A Journal of Practice \& Theory 33(4), 167-196. https://doi.org/10.2308/ ajpt-50814

Lennox, C.S., 2014, 'Auditor tenure and rotation', in D. Hay, M. Willekens \& W.R. Knechel (eds.), The Routledge companion to auditing, 1st edn., chapter 8, pp. 89-106, Routledge, Abingdon.

Lennox, C.S., Wu, X. \& Zhang, T., 2014, 'Does mandatory rotation of audit partners improve audit quality?', The Accounting Review 89(5), 1775-1803. https://doi. org/10.2308/accr-50800

Lu, T. \& Sivaramakrishnan, K., 2009, 'Mandatory audit firm rotation: Fresh look versus poor knowledge', Journal of Accounting and Public Policy 28(2), 71-91. https://doi.org/10.1016/j.jaccpubpol.2009.01.006

Maroun, W. \& Solomon, J., 2014, 'Whistle-blowing by external auditors: Seeking legitimacy for the South African Audit Profession?', Accounting Forum 38(2), 109-121. https://doi.org/10.1016/j.accfor.2013.04.007

Mccahery, J.A., Sautner, Z. \& Starks, L.T., 2016, 'Behind the scenes: The corporate governance preferences of institutional investors', The Journal of Finance 71(6), 2905-2932. https://doi.org/10.1111/jofi.12393

Monroe, G.S. \& Woodliff, D.R., 1994, 'Great expectations: Public perceptions of the auditor's role', International Journal of Auditing 4(8), 42-53. https://doi. org/10.1111/j.1835-2561.1994.tb00157.x

Myers, K.K. \& Oetzel, J.G., 2003, 'Exploring the dimensions of organizational assimilation: Creating and validating a measure', Communication Quarterly 51(4), 438-457. https://doi.org/10.1080/01463370309370166
Nelson, M.W., 2009, 'A model and literature review of professional skepticism in auditing', Auditing: A Journal of Practice \& Theory 28(2), 1-34. https://doi. org/10.2308/aud.2009.28.2.1

Nolder, C.J. \& Kadous, K., 2018, 'Grounding the professional skepticism construct in mindset and attitude theory: A way forward', Accounting, Organizations and Society 67, 1-14. https://doi.org/10.1016/j.aos.2018.03.010

Oddy, M., 2017, Chief Executive Officer of KPMG Inc. South Africa-Response to the IRBA Consultation Paper on MAFR, 20 January 2017, Received directly from KPMG Inc.

OECD, 2011, The role of institutional investors in promoting good corporate governance, viewed 24 July 2015, from http://www.oecd.org/corporate/ca/ corporategovernanceprinciples/theroleofinstitutionalinvestorsinpro motinggoodcorporategovernance.htm.

Peyper, L., 2017, New audit regulation won't improve independence - Auditors, Fin24 Online, 17 March, viewed 20 March 2017, from http://www.fin24.com/ Companies/Financial-Services/new-audit-regulation-wont-improveindependence-auditors-20170317.

Porter, B., HÓgartaigh, C. \& Baskerville, R., 2012, 'Audit expectation-performance gap revisited: Evidence from New Zealand and the United Kingdom', International Journal of Auditing 16(3), 215-247. https://doi.org/10.1111/j.1099-1123.2011.00444.x

Pozen, R.C., 2015, 'The role of institutional investors in curbing corporate shorttermism', Financial Analysts Journal 71(5), 10-12. https://doi.org/10.2469/faj. v71.n5.5

Ramon, K., 2016, 'The CFO forum response to IRBA's consultation paper', 04 November 2016, viewed 25 February 2017, from https://cfo.co.za/article/cfos-rejectmandatory-audit-rotation-christine-ramon.

Roush, P.B., Church, B.K., Gregory Jenkins, J., McCracken, S.A. \& Stanley, J.D., 2011, 'Auditor rotation: The PCAOB considers a new direction', Current Issues in Auditing 5(2), 15-20. https://doi.org/10.2308/ciia-50100

Shango, D., 2017, Chief Executive Officer of PWC Inc. South Africa-Response to the IRBA Consultation Paper on MAFR, 20 January 2017, Received directly from PwC Inc.

Sharenet, 2018, Sharenet JSE market statistics, viewed 28 February 2018, from http://www.sharenet.co.za/index.phtml?content=/free/topco.phtml.

Stefaniak, C.M., Robertson, J.C. \& Houston, R.W., 2009, 'The causes and consequences of auditor switching: A review of the literature', Journal of Accounting Literature $28,47-121$.

Tepalagul, N. \& Lin, L., 2015, 'Auditor independence and audit quality: A literature review', Journal of Accounting, Auditing \& Finance 30(1), 101-121. https://doi. org/10.1177/0148558X14544505

The Economist, 2018a, 'Reforming the Big Four - Shape up not break up', The Economist, 24 May, viewed 24 June 2018, from https://www.economist.com/ leaders/2018/05/24/reforming-the-big-four.

The Economist, 2018b, 'The great expectations gap. What is an audit for?', The Economist, 26 May, viewed 24 June 2018, from https://www.economist.com/ finance-and-economics/2018/05/26/what-is-an-audit-for. 